\title{
SOBRE SILÊNCIOS E SOMBRAS: DRUMMOND EM DIÁLOGO COM DANTE ALIGHIERI E MÁRIO DE ANDRADE
}

http://dx.doi.org/10.11606/issn.2237-1184.v0i34p163-184

Julio Augusto Xavier Galharte ${ }^{I}$

RESUMO

"Mário de Andrade desce aos infernos", de Carlos Drummond de Andrade, é o foco deste ensaio, em que se perscruta como um núcleo temático formado por palavra-silêncio e morte-vida é configurado em seus versos, levando em consideração seu desenho formal. A relação entre literatura e sociedade norteia a análise e a interpretação, em suas coincidentes e dessemelhantes feições apresentadas nos séculos XIII, XIV e XX, uma vez que, para sua avaliação, tomo como referências de comparação alguns textos de Dante Alighieri e Mário de Andrade, escritores evocados no título e nas estrofes desse poema do autor mineiro.

\section{ABSTRACT}

"Mário de Andrade descends into hell", by Carlos Drummond de Andrade, is the focus of this essay, in which it is examined how a thematic nucleus formed by wordsilence and death-life is configured in its verses, considering its formal design. The relationship between literature and society guides the analysis and interpretation - in their coincident and dissimilar features presented in the 13th, 14th and 20th centuries -, since, for its evaluation, I take as references for comparison some texts by Dante Alighieri and Mário de Andrade, writers evoked in the title and stanzas of this poem by the author from Minas Gerais.

\section{PALAVRAS-CHAVE:}

"Mário de Andrade desce aos infernos"; Silêncio; Palavra; Morte; Vida.

\section{KEYWORDS}

"Mário de Andrade descends into hell"; Silence; Word; Death; Life.

\footnotetext{
I Universidade de São Paulo, São Paulo, São Paulo, Brasil.
} 
Para Alfredo Bosi, com sua voz em permanência.

Há tantos diálogos / / [...]//Diálogo consigo mesmo/ com a noite/ os astros/ os mortos/

[...]// Escolhe teu diálogo/ e/ tua melhor palavra/ ou teu melhor silêncio/ Mesmo no silêncio e com silêncio/ dialogamos.

Carlos Drummond de Andrade, "O constante diálogo"1

\section{"0}

resto é silêncio". Nesta frase, que é uma das derradeiras em Hamlet, de William Shakespeare, imbricam-se várias vibrações semânticas, entre as quais a de que os passamentos acumulados ao longo da trama dramática geraram, em desfecho, a suspensão verbal. Nessa possível apreensão de significados, esse enunciado (que é do protagonista à beira do falecimento) é quase como o da própria morte, avisando que não seriam mais ouvidas as falas daqueles que ela carregou. No entanto, antes de essas palavras serem lançadas, a voz do pai de Hamlet, que já havia se embrenhado pelo "país desconhecido", ressoava nítida e vigorosa em algumas passagens da peça, tendo, inclusive, peso considerável para seu andamento. Os mortos parecem não aceitar a condição de mudos.

Essas deslizantes fronteiras entre o silêncio e a palavra por onde transitam os falecidos são também destaque em outra obra de grande importância para a literatura do Ocidente, A divina comédia, de Dante Alighieri (1979, 2019), na qual o poeta transformado em personagem percorre inferno, purgatório e paraíso na ânsia de escutar as sombras.

Visitar os mortos, com o ouvido atento ao seu verbo, é condição fundamental, segundo T. S. Eliot (1989), para um escritor ser considerado moderno. ${ }^{2}$ Em "Tradição e talento individual", o ensaísta, poeta e dramaturgo anglo-americano apresenta um rol de nomes do círculo da tradição ocidental, com que um autor teria que dialogar, colocando em ação sua habilidade criativa e reveladora de seu "talento individual".

\footnotetext{
${ }^{1}$ Este e outros poemas de Drummond transcritos neste ensaio foram lidos e consultados na sua Poesia completa. Vide bibliografia: Andrade (2007).

2 São palavras eliotianas: "Nenhum poeta, nenhum artista, tem sua significação completa sozinho. Seu significado e a apreciação que dele fazemos constituem a apreciação de sua relação com os poetas e artistas mortos" (ELIOT, 1989, p. 39).
} 
Assim, o passado literário não voltaria intacto, pois seria transformado pelas peculiaridades emanadas do autor contemporâneo, que deveria impregnar seu texto com as especificidades de seu tempo, seu lugar e sua subjetividade. Dentre vários nomes da tradição, Eliot menciona os já citados Shakespeare e Dante, que comparecem também à produção poética eliotiana, como, por exemplo, em "A terra desolada", poema emblemático do Modernismo, publicado em 1922, mesmo ano da Semana de Arte Moderna ${ }^{3}$, que tinha Mário de Andrade como principal mentor. Aquele que era "trezentos-e-cinquenta" e o criador de A divina comédia podem ser reconhecidos em vários textos de Carlos Drummond de Andrade, especialmente em "Mário de Andrade desce aos infernos", em que a presença do escritor paulistano e do autor florentino já é sinalizada no próprio título. Esse escrito é analisado neste ensaio, sendo necessário explicitar o critério dessa escolha. Ela decorre pelo fato de que esse texto pode favorecer uma leitura, entre tantas outras possíveis, que privilegia a confluência temática de silêncios, palavras, vida e morte. Ademais, esses elementos são passíveis de revelar a sociedade e o tempo a partir dos quais o poema se originou, do mesmo modo como ocorre com as produções literárias da lavra do italiano Dante Alighieri e do brasileiro-paulista Mário de Andrade. Assim, os escritos dantescos dos séculos XIII e XIV, bem como os textos mariodeandradianos do século XX, são convidados a uma participação nestas dinâmicas de análise e interpretação, nas quais são perseguidas as especificidades do verbo e dos silêncios poéticos de Carlos Drummond de Andrade, que teve seu trânsito de existência entre Itabira e Rio de Janeiro, no intervalo de 1902 a 1987.

\section{"Quente Quietude"4}

Mergulhando a imaginação nos vermelhos Reinos feéricos e cabalísticos de Satã, [...], encontrei um dia Baudelaire, [...], estava mudo, imóvel, com o seu perfil suavemente cinzelado e fino, [...]. E eu, então, murmurei-lhe, quase em segredo: - Charles, [...]. Ah! se tu soubesses com que encanto ao mesmo tempo delicioso e terrível, inefável, eu gozo todas as tuas complexas, indefiníveis músicas; [...].

Cruz e Sousa, "No inferno"

\footnotetext{
${ }^{3}$ Também ocorre em 1922 a primeira edição do Ulysses, de James Joyce, morada de inovações que convivem com ecos da tradição.

${ }^{4}$ Essa expressão é de João Guimarães Rosa e está em "Os chapéus transeuntes", do livro Estas estórias.
} 
Numa conhecida obra trecentista, um falante e movimentado Virgílio apresenta o Inferno a seu admirador Dante. Este, no périplo, descobre que os próximos locais a serem devassados são o Purgatório e o Paraíso. Cinco séculos depois, Cruz e Sousa, num dos textos de Evocações, projeta-se também às zonas profundas e encontra um "mudo, imóvel" Baudelaire, não havendo, neste caso, convites para vindouras escaladas em universos altivos e iluminados. $\mathrm{O}$ mundo sombrio, tão inóspito para os personagens do século XIV, parece muito mais atraente, tendendo a se bastar, para essa outra dupla do século XIX. Por quê? Talvez porque o inferno seja o espaço literário mais confortável para almas inquietas, como a do criador de As flores do mal e a do autor de Broquéis, fazendo com que este para homenagear aquele o assente exatamente ali.

O procedimento laudatório de "No inferno", de Cruz e Sousa, aproxima-se do empreendido em "Mário de Andrade desce aos infernos", de Drummond, que parece ter atualizado no século XX algumas inquietudes daqueles dois poetas que o antecederam. Antonio Candido, em um ensaio da década de 1960, já apontava para a energia da inquietação que alimentava os "eus" poéticos do escritor mineiro, indicando que os sujeitos de sua lírica se angustiavam no movimento entre individualidade e coletividade, presente e passado, vida e morte e outros pares de abstração, nunca se sentindo totalmente cômodos em apenas uma dessas zonas, mesmo quando tentavam conciliá-las. (CANDIDO, 1977, p. 93-122). Levando em conta essas reflexões de Candido e voltando ao "No inferno" de Cruz e Sousa, há um trecho que parece caracterizar quase totalmente os sujeitos drummondianos: "Nos olhos [de Baudelaire] dominadores e interrogativos, cheios de tenebroso esplendor magnético, pairava a ansiedade, uma expressão miraculosa, um sentimento inquietador e eterno do Nomadismo..." (SOUSA, 1889, p. 232).

$\mathrm{O}$ olhar interrogativo, pertencente a um sujeito embalado por um nomadismo inquietador, pode ser percebido em "Mário de Andrade desce aos infernos". Trata-se de um canto "ziguezagueante, rouco", que oscila entre imagens desoladamente escurecidas e lumes de positividade. Essas oscilações talvez se devam ao tempo histórico em que o escrito foi publicado. O ano de 1945, no qual se lançou o texto, foi enigmático. Por um lado, alguns tormentos se findavam, como os do período totalitário estadonovista (1937-1945), da Segunda Grande Guerra (1939-1945) e da prisão de Luís Carlos Prestes (1940-1945). ${ }^{5}$ Por outro lado, muitas dores vindas do passado ainda repercutiam naquele presente, que abrigava também

\footnotetext{
${ }^{5}$ Logo no início de 1945, de 22 a 27 de janeiro, foi realizado o I Congresso Brasileiro de Escritores, com discursos fortemente contrários ao governo Vargas. Organizado pela Associação Brasileira de Escritores, esse evento e as publicações a ele associadas reivindicavam, por exemplo, o fim da censura para os escritores. Foram montadas várias comissões para a sua realização, inclusive, a de "assuntos políticos", da qual fez parte Drummond.
} 
dúvidas e inseguranças sobre o futuro. É dessa terra em turbulência, vibrando com as energias dos temores e das esperanças, visitada pelo sol das expectativas e regada com o sangue dos mortos, que nasceu $A$ rosa do povo, obra na qual o poema "Mário de Andrade desce aos infernos" foi inserido. Penetravam aquele chão de palavras os áporos (os insetos em aporia desdobrados em orquídeas), bem como as ondas amorosas, que tentavam atingir os enterrados, como o autor de Amar verbo intransitivo, falecido naquele ano.

Por que, para prestar homenagem ao morto, no texto que se perscruta, são evocados os infernos e as descidas, ao invés dos paraísos e das subidas? Provavelmente os céus trariam certezas e sensações de completude, dispensáveis tanto a esse sujeito poético (e ao homenageado) como para o andante de "A máquina do mundo", como notou Alfredo Bosi na interpretação deste poema de Claro enigma. $\mathrm{O}$ crítico mostra que no canto XX do "Paraíso", no oitavo céu, Dante "recebe de Beatriz o convite para contemplar o mundo inteiro a seus pés" e, lá, o poeta desdenha da "pequenez do nosso mundo", com ares de "juiz soberbo". A poesia de Drummond, imersa num tempo em que a "realidade tornou-se infinitamente mais complexa, e a sua decifração, na era da ciência, infinitamente mais árdua", "quando ousa falar do cosmos, traz no seu canto chão o acento da perplexidade: 'enquanto eu/ avaliando o que perdera,/ seguia vagaroso, de mãos pensas' “ (BOSI, 2003, p. 120-121).

O poema "A máquina do mundo" coincide com $A$ divina comédia na escolha das "tercinas em decassílabos" (VILLAÇA, 2006, p. 87), mas põe-se avesso à rima, tão presente em Dante (BOSI, 2003, p. 120), e apresenta um "movimento mais lento, mais travado e complicado" (TITAN JR., 2012, p. 119). Ciclicamente, chamar Dante e dispensá-lo, celebrando uma tensão no fazer literário na sua relação com a tradição, são dinâmicas que já se percebiam no primeiro livro de Drummond. Em Alguma poesia (dedicado a Mário de Andrade), o "Nel mezzo del cammin" inicial de A divina comédia é evocado no verso inaugural e no título de "No meio do caminho". Mas se as primeiras palavras do Inferno e desse texto drummondiano aproximam-se, o que se lê na sequência de um e de outro escrito os lança a lonjuras consideráveis tanto nas suas estruturas quanto nas configurações de seus sentidos. Os versos brancos, a assimetria, o encurtamento verbal e a intensa repetição lexical de No meio do caminho contrapõem-se às rimas, à simetria e ao discurso poético longo, pautado na variedade vocabular d' $A$ divina comédia. No enfeixar das distâncias semânticas desses poemas, reconhecíveis na apresentação das imagens, pode-se detectar, por exemplo, que o sujeito drummondiano, diferentemente do dantesco, não 
tem um guia6 (chamado por uma intercessão divina) a seu lado para esclarecer-lhe dúvidas sobre o que se coloca diante de seus olhos, pois o "eu" poético do escritor brasileiro prostra-se solitário, sem o amparo de qualquer ordem, diante de um signo, imantado de enigmas. Cito uma dessemelhança outra, neste caso apontada por Dall' Alba (1996, p. 29): “O caminho de Drummond" é "rente ao solo" e "não há espiralantes divagações [...], nem outro inferno que não seja o mundo moderno". Parece que é esse universo infernal da modernidade que se faz aparecer em "Mário de Andrade desce aos infernos", para, inclusive, expressar os sentimentos de um sujeito que "no meio do caminho" encontra uma morte (a pedra tornou-se lápide?). Para Drummond, o morto era tido como importante referência moderna, com seus escritos nos quais cabiam também os conteúdos dos mitos e de elementos mais antigos, submetidos à ressignificação.

"Mário de Andrade desce aos infernos" apresenta-se em quatro partes (divididas pelo próprio autor), com variados tamanhos. Indico, entre parênteses, a quantia de suas estrofes: primeira (2), segunda (4), terceira (1) e quarta (7). Na passagem de um segmento a outro, nota-se que o texto começa curto, na sequência se amplia, depois se contrai e, ao cabo, volta a crescer. Um desenho parecido com esse se apresenta aos olhos quando se atenta para as extensões dos versos no interior de uma mesma estrofe (inclusive na terceira seção, quase toda formada por redondilhas maiores, pois um tetrassílabo e um dissílabo se intrometem ali para tirar o discurso poético da simetria). Esse canto é, portanto, em quase todo seu fluir, "ziguezagueante". A irregularidade movimenta o poema, que também se abre à regularidade, não tendo sossego em apenas um andamento para seus versos. O escrito, logo em seus trechos iniciais, abriga uma convenção poética, pautada na repetição, a anáfora: "Daqui a vinte anos farei teu poema/ e te cantarei com tal suspiro/ que as flores pasmarão, e as abelhas,/ confundidas, esvairão seu mel.// Daqui a vinte anos: poderei/ tanto esperar o preço da poesia?/ [...]"

Versos eneassílabos compõem toda a primeira estrofe e ainda permanecem no início da segunda, mas há uma ruptura nessa organização com a expansão das sílabas poéticas no segundo e terceiro versos ("tanto esperar o preço da poesia?/ É preciso tirar da boca urgente") e principalmente no quarto ("O canto rápido, ziguezagueante, rouco). Na sequência, há lugar para o decassílabo ("e de vozes em febre, que golpeiam"), para o retorno ao eneassílabo ("esta viola desatinada") e para o remate em tetrassílabo ("no chão, no chão"). O canto ziguezagueante está posto.

\footnotetext{
${ }^{6}$ Virgílio é o guia de Dante no Inferno e Purgatório; Beatriz e São Bernardo assumem esse posto no Paraíso.
} 
A oscilação formal dessa primeira parte do poema parece refletir a condição titubeante do sujeito poético ante as dimensões temporais, pois na primeira estrofe promete escrever no futuro um poema para homenagear o amigo ("Daqui a vinte anos farei teu poema/ e te cantarei..."; o grifo é meu), mas subitamente muda, na segunda estrofe, e encadeia no imediato presente seus versos ao morto ("É preciso tirar da boca urgente/ o canto rápido, ziguezagueante, rouco/ feito da impureza do minuto/ e de vozes em febre"; o grifo é meu). Ao longo do poema, a ação em curso da escrita registra o estado de espírito atualizado do sujeito poético diante do recente e fatal acontecimento envolvendo seu amigo. Este é procurado no passado, configuração temporal que vem e vai, deixando seu grifo em vários versos com registro memorialístico.

Além de ser marcado pelo ziguezague da métrica e do tempo, esse poema é afeito à ciclicidade. Como se viu, o escrito começa com o retinir de uma anáfora ("Daqui a vinte anos") nos versos iniciais da primeira e da segunda estrofe. Ademais, a expressão "no chão", além de se duplicar no fechamento dessa primeira divisão do poema, é retomada no início da sua segunda seção ("No chão me deito à maneira dos desesperados"), num registro simultâneo de outra anáfora (considerando o primeiro "no chão" ao final da primeira parte) e de uma anadiplose (levando em conta o segundo "no chão" daquele mesmo verso e as palavras iniciais do segundo segmento do escrito).

A anadiplose foi reconhecida por Davi Arrigucci Jr. (2002) em outro texto de A rosa do povo, "Áporo", em sua estrofe primeira: “Um inseto cava/ cava sem alarme/ perfurando a terra/ sem achar escape" (o grifo é meu). Para o crítico, o ciclo de repetições desse poema, que não se interrompe nessa anadiplose, acolhe um sentido mítico ligado à imagem da metamorfose (remetendo às Metamorfoses, de Ovídio) e do labirinto (tendo certos vínculos com a narrativa grega que envolve os personagens Dédalo, Minotauro e Ariadne). Mas o mito é recodificado no ambiente mais complexo da História ("país bloqueado"). ${ }^{7}$

Mito e História também confluem nas obras do homenageado de "Mário de Andrade desce aos infernos", principalmente em Macunaíma, inspirado em mitos dos Taulipang e na realidade do Brasil dos anos 1920. A ciclicidade dessa obra se manifesta de várias maneiras, uma delas se dá pela não-palavra, que está em cada uma das pontas da narrativa, se bem que com mudança de configuração semântica, como indica Maria Augusta Fonseca: "o silêncio do início da história precede o relato do nascimento do

\footnotetext{
7 Dante, nos três mundos de A divina comédia, retoma com alterações, como Drummond, o universo de Ariadne, Minotauro e Dédalo. No escrito do século XIV, esses e outros personagens míticos (como Medusa, Netuno, Electra, Orfeu, Júpiter e Tirésias, por exemplo) convivem com figuras históricas, tais como Bonconte de Montefeltro, Cangrande Della Scalla, Carlos Martel, Justiniano etc.
} 
herói. Contrapõe-se ao silêncio do epílogo, 'acabou-se a história e morreu a vitória' (final à moda do fabulário popular), e ao silêncio do fim escolhido pelo herói: ser 'brilho inútil' de estrela" (FONSECA, 2006, p. 107).

A suspensão do verbo, associada à morte, é tematizada em vários trechos de "Mário de Andrade desce aos infernos", inclusive em sua segunda parte: "[...]/ Não quero, mas preciso tocar pele de homem,/ Avaliar o frio, ver a cor, ver o silêncio,/ [...]./ Estou cego e vejo. Arranco os olhos e vejo./ Furo as paredes e vejo. Através do mar sanguíneo vejo./ [...]". Instaura-se aí uma "poética do olhar"8, estabelecida nas repetições do verbo ver, que surge duas vezes no infinitivo ("ver") e quatro vezes no presente do indicativo, conjugado na primeira pessoa do singular ("vejo", que se coloca ao final dos versos). Mesmo quando se arrancam os olhos (essa imagem, diga-se de passagem, tem parentesco com as do universo infernal de Dante), ainda assim se vê. No início dessa segunda divisão do poema, só é possível ver (e não ouvir) o morto. Mário morto é um outro que parece entregue à mudez, aos olhos do sujeito poético: "Não quero, mas preciso tocar pele de homem/ avaliar o frio, ver a cor, ver o silêncio" (o grifo é meu). Aquele que é objeto da mirada, "com seus lábios imóveis"9, seria então alguém cujo fluir verbal foi interrompido com a morte? Uma resposta afirmativa e taxativa ignoraria a continuidade dos versos, pois lêse adiante que o dizer do amigo (alterado em seus sentidos pela morte), persiste sem pausa e aos poucos: "Minucioso, implacável, sereno pulverizado,/ é outro amigo. São outros dentes. Outro sorriso./ Outra palavra, que goteja". Goteja também a palavra desse sujeito drummondiano que prossegue a homenagem, que se dá a custo, sob o imperativo da necessidade: "preciso aceitar e compor, minhas medidas partiram-se,/ mas preciso, preciso, preciso".

O primeiro verso dessa segunda parte do poema ("No chão me deito à maneira dos desesperados") - que forma, solitariamente, a estrofe inicial - é digno de atenção. Se continuarmos na perspectiva comparada e chamarmos mais uma vez A divina comédia para o diálogo, observaremos que Drummond inverte a organização apresentada no "Inferno", pois, neste, o verso único, compondo uma estrofe, é sempre o derradeiro em todos os cantos. Qual a razão da inversão? Talvez haja a sugestão de que a modernidade, em certos aspectos, colocou de ponta-cabeça o mundo

\footnotetext{
8 A expressão é de Regina Lúcia Pontieri (1999), que aparece como subtítulo de seu livro sobre Clarice Lispector em que analisa esse tema na obra da escritora.

${ }^{9}$ As palavras entre aspas são de Mário Quintana e pertencem ao seu poema "A canção", que cito a seguir quase integralmente, por guardar relações com o escrito drummondiano em análise: "Era a flor da morte/ E era uma canção.../ Tão bonita que só se podia ler dançando/ estava fragilmente pintada sobre o véu do silêncio/ onde a morta jazia com seus cabelos esparsos/ [...] com seus lábios imóveis/ E que talvez houvessem desaprendido para sempre até as sílabas com que outrora pronunciavam seu nome...".
} 
medieval no qual foi escrito o texto do autor italiano. O teocentrismo já não vigora, há uma coleção de desilusões e as feridas já não são curadas pela crença, tão importante para Dante, que, apesar de ter críticas a algumas tendências do Catolicismo ${ }^{10}$, criou uma obra defensora da fé em Deus ${ }^{11}$, evidenciando a busca de estabilidade, proporcionada pela convicção. Em chave diversa, no texto de um ateu, esse universo é invertido e o homem se centraliza, mas o matiz não é renascentista, pois o homem não está empolgado com suas invenções e descobertas e sim inerte em sua impotência, e cercado de limites, ao menos esse é o tipo de sujeito que surge com certa regularidade nos escritos de Drummond.

A instabilidade estrutural toma conta dos versos da segunda parte de "Mário de Andrade desce aos infernos", em que a retidão da simetria é dispensada de maneira mais contundente do que na primeira seção do poema, pois ocorre larga oscilação no número de sílabas poéticas, que vão de 8 a 17 sílabas. Essa forma instável espelha o fundo desses versos, quando se pensa na morte, com seu poder desestabilizador ("minhas medidas partiram-se"), principalmente porque ela recai sobre alguém tão importante para a vida e a obra de Drummond: "Rastejando, entre cacos, me aproximo". Merece atenção o trecho que antecede este último verso citado, em que fonemas semifechados e fechados preponderam: “EstOU EscUrO, EstOU rIgOrosamentE nOtUrnO, EstOU vazIO”. Criase pela sonoridade uma atmosfera cerrada, escura e pesarosa, principalmente por causa da vogal " $u$ ", que, como indica Alfredo Bosi, em "O som no signo", por ser grave, fechada, velar e posterior, pode evocar, "por analogia, sentimentos de angústia e experiências negativas, como a doença, [...], a tristeza e a morte". (BOSI, 1977, p. 46)

Essa segunda parte do poema, em comparação com a primeira, se espraia na página, pois, como se viu, o menor verso é um octossílabo e a preponderância é de versos mais longos de até 17 sílabas poéticas. Nesse contexto de alargamento, pode-se também ampliar o sentido da morte, pensando em 1945, quando Mário faleceu, pois era um passamento no meio de milhões de outros sucedidos desde 1939, se se contabilizam as baixas da Segunda Grande Guerra, com seus 75.000.000 de mortos, aproximadamente, um número aterrorizador por si e por comparação com os 20.000.000 que pereceram na Primeira Grande Guerra. No caso do conflito mais recente, a bomba atômica com seu devastador poder de

\footnotetext{
10 Vide alguns Papas sendo punidos no "Inferno", como Nicolau III, Anastácio II, Bonifácio VIII e Clemente V.

${ }^{11}$ Carmelo Distante, no prefácio à tradução de Italo Eugenio Mauro de A divina comédia, aponta o seguinte: “[...], o homem sem Deus é para Dante um ser perdido, no sentido de que jamais poderá encontrar em si mesmo a razão última e verdadeira da própria vida. Por isso, no cume de toda especulação filosófica deveria estar a procura de Deus, isto é, a teologia". (DISTANTE, 2019, p. 7)
} 
aniquilamento se somou às armas de fogo já existentes multiplicando o número de vítimas no evento devastador.

A ampliação da "população" de falecidos no mundo reverbera na poesia de Drummond, em que a presença dos mortos cresce consideravelmente do primeiro livro até $A$ rosa do povo (se fizermos um recorte no histórico de publicações drummondianas que nos interessam por ora), principalmente nas obras editadas no período da Segunda Grande Guerra: Sentimento do mundo (1940) e José (1942). Deste último, o poema "Os rostos imóveis" apresenta um mundo em pleno extermínio massivo: "Pai morto, namorada morta, [...] inimigo morto, [...]. Morto sem notícia, morto secreto. [...] eram casas de mortos, ondas desfalecidas. [...] [a cidade] toda se queimava/ estalar de bambu/ boca seca logo crispada".

Em "Os rostos imóveis", "Canção do berço" (de Sentimento do mundo) e "Resíduos" (de A rosa do povo), Jaime Ginzburg sublinha o universo de ruínas de sujeitos poéticos mergulhados na melancolia, às voltas com a avaliação de suas perdas. Esse tipo de poesia, segundo o crítico, reflete bastante os anos 1940, axiais para o historiador Eric Hobsbawm se referir ao século XX como a "era das catástrofes". (GINZBURG, 2012, p. 332).

O inferno cheio de sombras dessas obras de Drummond é mais dramático do que aquele de Dante, que também abrigava os mortos de guerras, mas estas eram isentas ainda de armas atomicas e campos de concentração. Adorno entendia que após Auschwitz a escrita de um poema era um ato de barbárie, o que deveria resultar no silêncio da lírica. Drummond prosseguiu criando versos, mas neles imprimem-se vários mutismos, inclusive aqueles resultantes da estupefação diante dos tempos bárbaros. Walter Benjamin já enunciava, em "O narrador", que o conflito mundial (ele escreve o ensaio após o primeiro deles) exterminou muitas vozes: "No final da guerra, observou-se que os combatentes voltavam mudos do campo de batalha não mais ricos, e sim mais pobres em experiência comunicável". (BENJAMIN, 1994, p. 198). N'A rosa do povo, os emudecimentos são abundantes. Em "Visão de 1944", tem-se uma "massa de silêncio concentrada" que aguarda "a passagem dos soldados"; em "Rola mundo", impõe-se a pergunta: "Como pois interpretar o que os heróis não contam?"; o sujeito de "Mas viveremos" atesta: "Que dificuldade de falar!".

O verbo se ausenta ou comparece custoso nessa e em outras obras drummondianas; há uma terceira possibilidade: ele (o verbo) se restringe, resultando numa poesia com "um sinal de menos" 12 , como ocorre de modo mais radical em "Ausência de Rodrigo" de As impurezas do branco, principalmente em sua última estrofe:

${ }^{12}$ Trecho de "Poema-orelha", do livro A vida passada a limpo. 


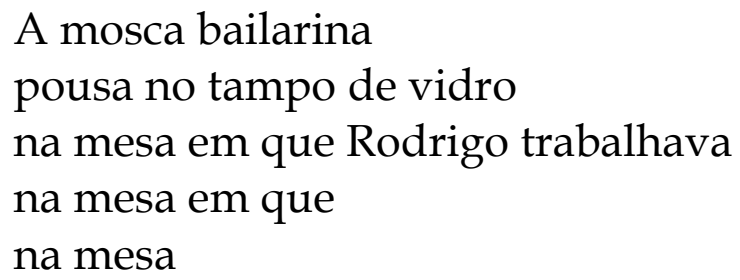

na.

Betina Bischof observa que nesse poema, feito para homenagear Rodrigo Melo Franco de Andrade13, falecido em 1969, "são a ausência da palavra, o verso carcomido, a dissolução da expressão que nos dão notícia da morte" (BISCHOF, 2005, p. 101). A imagem do dizer que se esfacela gradualmente faz parte, segundo a crítica, de um repertório mais amplo de Drummond, que percorre várias de suas obras, em que se apresentam os efeitos devastadores da passagem do tempo nas pessoas, nos lugares (principalmente nas terras mineiras esboroadas pelos ciclos de exploração econômica), nas coisas etc. O que sobram são resíduos resultantes da ação histórica, por isso tantos poemas sobre a dissolução, provenientes de um olhar crítico que incide não só no passado, mas também no presente.

\section{Dizer e desdizer diamantinos}

$$
\begin{array}{r}
\text { Saber de cor o silêncio/ } \\
\text { diamante e/ou espelho } \\
\text { o silêncio além } \\
\text { do branco. } \\
\text { Saber seu peso } \\
\text { seu signo }
\end{array}
$$

\author{
Saber seu centro: vazio \\ esplendor além \\ da vida \\ e vida além da memória. \\ Saber de cor o silêncio \\ - e profaná-lo, dissolvê-lo
}

${ }^{13}$ Drummond tinha vínculo de amizade e trabalho com o homenageado, tendo ambos um longo convívio no Patrimônio Histórico e Artístico Nacional, no período de 1945 a 1962. (BISCHOF, 2005, p. 101). 
em palavras.

Orides Fontela, "Poema"

Uma contração verbal (não tão radical quanto a que se mostra ao cabo do poema "Ausência de Rodrigo") é apresentada na terceira parte de "Mário de Andrade desce aos infernos", pois tudo se concentra em uma única estrofe, menor do que as das outras seções do poema, contendo versos mais apertados. Esse segmento do escrito é formado quase totalmente por redondilhas maiores (sete sílabas), com duas exceções, em que aparecem versos mais encolhidos: o tetrassílabo "dos Sete Saltos" e o dissílabo "fantásticos". No entanto, apesar do fechamento estrutural, essa divisão do texto permite-se mais aberta (e luminosa) do que as antecedentes na sua movimentação semântica. Há certos fulgores de leveza, associados à evocação das memórias magnetizadas de positividade, em que se constata, por exemplo, um farto legado deixado pelo morto. Em uma das passagens, um diálogo com A divina comédia parece ganhar mais corpo, pois Mário de Andrade se afigura para Drummond quase como seu Virgílio. Mas o itinerário se apresenta distinto daquele da obra trecentista:

O meu amigo era tão/ de tal modo extraordinário,/ cabia numa só carta,/ esperava-me na esquina/ e já um poste depois/ ia descendo o Amazonas,/ tinha coletes de música/ entre cantares de amigo/ pairava na renda fina/ dos Sete Saltos,/ na serrania mineira

Multifacetado, esse guia do sujeito poético passa de flâneur a navegador "aprendiz": "esperava-me na esquina/ e já um poste depois / ia descendo o Amazonas". Se Dante e Virgílio põem-se tête-à-tête para o périploaprendizagem, Drummond e Mário se envolvem em proveitosas e densas conversas, sem saírem de casa, apartados pela distância. As missivas eram o veículo da aproximação e da entrega: "O meu amigo era tão/ de tal modo extraordinário,/ cabia numa só carta". Mário parece mesmo ser, em vários aspectos, o mestre de Drummond ${ }^{14}$, pois, não por acaso, o escritor mineiro dá o título de $A$ lição do amigo ao livro que reúne as correspondências do autor paulistano remetidas a ele. Além disso, na apresentação desse volume, Drummond destaca o "vínculo afetivo", selado a partir do início da troca de cartas, que "marcaria em profundidade" sua "vida intelectual e moral" e conclui: "constituindo o mais constante, generoso e fecundo estímulo à atividade literária, por mim recebido em toda a minha existência". (ANDRADE, 2015, p. 10).

\footnotetext{
${ }^{14}$ Esse posto era movente, deixando-se intercambiar.
} 
Drummond, pela lição do amigo, deixou de sentir-se francês e de querer soar como Anatole France, "aquela peste amaldiçoada", com seus artificialismos e seu distanciamento da realidade do mundo, segundo Mário de Andrade. ${ }^{15}$ Este último, por sua vez, recebeu do escritor mineiro algumas críticas, como a de que não era poético ao apresentar alguns assuntos imediatos: "Você me parece ceder por vezes à ânsia de comunicar coisas urgentes que estão se passando no seu íntimo e que não são propriamente poesia. Coisas que dariam provavelmente um discurso..."16

Referências a Dante aparecem nos textos epistolares dos Andrades, principalmente os redigidos por Mário, como o remetido a Drummond no dia 11 de fevereiro de 1945, em que comenta sobre O pico dos três irmãos, obra que não saiu do projeto, pois o falecimento do autor (ocorrido poucas semanas depois do envio da carta) não permitiu sua realização. $\mathrm{Na}$ proposição, Drummond, Manuel Bandeira e Murilo Mendes apareceriam como os "irmãos" referidos no título. Incluindo-se no grupo, Mário associa os quatro ao quarteto que desfruta da fraternidade "límbica de Dante" (ANDRADE, 2002, p. 538), numa alusão aos autores clássicos reunidos no limbo do "Inferno" (no Canto IV): Homero, Horácio, Ovídio e Lucano.

Em outra missiva, bem anterior, do dia 15 de outubro de 1928, Mário se compara a Dante e a outros autores da tradição ocidental, por conciliar literatura e escrutínio social:

Outra bobagem do Tristão [de Ataíde] dizer que sou sociólogo e não artista, justamente diante da mais artística das minhas obras [Macunaíma]. Como se Dante, Cervantes, Camões et caterva não fossem artistas porque são sociólogos! Desculpe lembrar os grandões mas positivamente seria bobagem citar, no momento, Romain Rolland ou não sei que mais". (ANDRADE, 2002, p. 339).

Um dos motivos que fez de Dante um dos "grandões", para usar o termo de Mário, é exatamente o seu olhar voltado para a sociedade, devolvendo ao homem seu estatuto de ser histórico, sequestrado no começo do período medieval, como indica Erich Auerbach, em Dante, poeta do mundo secular:

No começo da Idade Média o sentido histórico ficara embotado - a imagem do homem estava reduzida a uma abstração moral ou espiritualista, um sonho remoto e lendário, ou uma cômica caricatura. Em resumo, o homem foi retirado de seu habitat natural, histórico. Com Dante, o indivíduo histórico renasceu em

\footnotetext{
${ }^{15}$ Essas opiniões sobre Anatole France são expressas em uma carta de Mário a Drummond, sem referência de dia e mês, escrita em 1924 (ANDRADE, 2002, p. 67-72).

${ }^{16}$ Carta de Drummond a Mário de $1^{\circ}$. de janeiro de 1931 (ANDRADE, 2002, p. 401).
} 
sua unidade manifesta de corpo e espírito. (AUERBACH, 1997, p. 219).

A mirada em direção ao homem social e histórico, que se encontra na literatura de Mário (com respaldo em Dante), revela-se na terceira parte de "Mário de Andrade desce aos infernos", na qual Drummond ressalta no morto seu desejo de ver mais humanidade e justiça em seu país - com a valorização dos desvalidos, espalhados "no mangue, no seringal, nos mais diversos brasis" - e em terras outras ("e para além dos brasis"), com potência para se transformarem em espaços utopicamente retraçados: "nas regiões inventadas,/ países a que aspiramos,/ fantásticos". A energia utópica movimenta os versos de outro poema d'A rosa do povo, "Cidade prevista":

Cantai esse verso puro/ que se ouvirá no Amazonas/ na choça do sertanejo/ e no subúrbio carioca, no mato, na vila $X, /$ no colégio, na oficina,/ território de homens livres que será nosso país/ e será pátria de todos. [...]/ Um mundo enfim ordenado,/ uma pátria sem fronteiras,/ sem leis e regulamentos,/ uma terra sem bandeiras, sem igrejas nem quartéis,/ [...]./ Este país não é meu/ nem vosso ainda, poetas./ Mas será um dia/ o país de todo homem.

De volta às cartas, em 29 de novembro de 1925, Mário anuncia: "Ando construindo um livro que deve sair engraçadinho, me parece. Talvez se chame Livro do amor. Prosa e verso de mistura, uma espécie de Vita nuova".17 (ANDRADE, 2002, p. 162). Essa obra do escritor italiano, escrita no século XIII, antes de $A$ divina comédia, é constituída em sua maior parte de parágrafos nos quais são inseridos trechos em versos, do próprio Dante. As passagens em prosa ora têm cunho narrativo, ora ganham feição de texto analítico, em que se comentam os poemas apresentados 18 , o que não chega a se configurar como parte de um ensaio, se pensarmos nas reflexões de Theodor Adorno (2003) sobre esse gênero. Para o estudioso da Escola de Frankfurt, um escrito ensaístico tem como uma de suas características a opacidade, a qual é rejeitada em Vida Nova com seu didatismo e até redundância nos comentários sobre os versos.

Ao somar poesia e prosa em Vida nova, Dante dá importante passo na história da literatura ocidental, principalmente porque seu texto acaba

\footnotetext{
17 Para Câmara Cascudo, Mário comenta, também em carta (de 26 de novembro de 1925), o mesmo projeto de Livro do amor: "É uma misturada de versos e prosa, mais ou menos no gênero de Vita nuova de Dante. Não repare na vaidade do modelo tão grande. Não implica que eu me compare com ele, Deus me livre, cada macaco no seu galho". (ANDRADE, 1991, p. 47).

${ }^{18}$ Vida nova tem, como temas principais, o amor, a morte e o fazer poético. Todos eles se ligando à Beatriz, a amada de Dante.
} 
tendo um efeito questionador sobre a pureza dos gêneros literários, que era tão fundamental no pensamento clássico. Essa revisão seria retomada no século XVIII pelos pré-românticos alemães, no XIX pelos românticos e simbolistas de muitas nacionalidades e no XX pelos modernistas de várias partes do mundo. Em favor da liberdade criativa, foram criados muitos textos híbridos, em que prosa e poesia perdiam suas divisas, o que foi defendido por Benedetto Croce (1886-1952). O crítico italiano é citado por Mário de Andrade em carta a Drummond (de 23 de novembro de 1926), na qual o remetente questiona o destinatário sobre seu conceito de conto: “Você me demonstrou um conceito apertado e dogmático do conto. Não aceito não. [...]. E veja, hoje, todos os gêneros se baralham, isso até Croce já decretou e está certo. Romances que são estudos científicos, poemas que são apenas lirismo, contos que são poemas, histórias que são filosofias etc. etc." (ANDRADE, 2002, p. 262).

O questionamento de Mário, feito em 1926, parece ter tido boa repercussão no pensamento e na escrita de Drummond que passou a publicar livros, a partir de 1930, nos quais textos lábeis quanto ao gênero eram apresentados. É o caso de "Outubro 1930", “Voo sobre as igrejas", (ambos publicados em Brejo das almas, de 1934) e "A um hotel em demolição"19 (de A vida passada a limpo, de 1959), que reúnem em seu corpo textual estrofes e parágrafos, como Vida nova, de Dante, mas sem o tom didático daquele escrito, inclusive porque o mineiro se serve de elementos ensaísticos, como a opacidade. ${ }^{20}$ Drummond, com o "poder de silêncio" 21 da sua "palavra indireta" 22, escolhe caminho oposto ao do escritor italiano, servindo-se de enigmas e subtextos, o que recebeu as seguintes observações de Antonio Candido:

O poema é, para além das palavras, uma conquista do inexprimível que elas não contêm e diante do qual devem capitular, mas que pode manifestar-se como sugestão misteriosa nas ressonâncias que elas despertam uma vez combinadas adequadamente; e que, indo perder-se nas áreas de silêncio que as cercam e se insinuam entre elas, são uma propriedade do poema no seu todo (CANDIDO, 1977, p. 119).

\footnotetext{
${ }^{19}$ Em "A um hotel em demolição", o autor de Macunaíma é citado: "Chope da Brahma louco de quem ama/ e o Bar Nacional pura afetividade/ súbito ressuscita Mário de Andrade". Esse escrito é dedicado a outro "morto": o Hotel Avenida, no qual Mário se hospedava quando ia para o Rio de Janeiro (MERQUIOR, 1975, p. 170).

${ }^{20}$ Além de traços de ensaio, "A um hotel em demolição" contém marcas de conto, crônica e da já dita poesia.

${ }^{21}$ Trecho do poema "Procura da poesia", que está em A rosa do povo.

${ }^{22}$ A expressão está em "Nosso tempo", de $A$ rosa do povo.
} 
"Um segredo comunica-se", lê-se na quarta, última e mais longa divisão de "Mário de Andrade desce aos infernos"23, em que o silêncio associado às palavras marca presença, principalmente em seu final. Mas tratemos, antes, do começo desse segmento que apresenta este verso: "A rosa do povo despetala-se" (os grifos são meus); daí se retirou o título do livro. A mesma expressão aparecia no último verso da parte anterior: "A rosa do povo aberta...". Isso, além de reforçar o caráter cíclico do texto drummondiano (apoiado nas repetições), que tenta espelhar a ciclicidade de vários textos de Mário de Andrade, sugere a importância do homenageado na formação de um Drummond mais preocupado com o povo.

A "gente pobre" 24 com sua cultura rica ganhou o silêncio da escuta de Mário, ouvinte atento das vozes populares em seus ditados, suas histórias e suas canções profanas e sagradas: "há um ouvido mais fino que escuta, um peito de artista que incha, / e uma rosa se abre" para "os cantadores, a gente de pé-no-chão,/ a voz que vem do Nordeste, os fetiches, as religiões". Plutarco, em "Elogio do silêncio", quarta seção de seu tratado Como ouvir, já indicava, na Antiguidade, que "o ouvido é o órgão da sabedoria" (PLUTARCO, 2003, p. 9) e servia-se inclusive da fala popular para atestar a importância da mudez audiente: temos dois ouvidos e uma boca. O sujeito do poema "Improviso do mal da América" (do livro Remate de males), de Mário de Andrade, comunga com esse pensamento popular, assimilado no discurso plutarquiano: "meus ouvidos vão escutar amorosos/ Outras vozes de outras falas, de outras raças, mais formação, mais forçura". (ANDRADE, 2013, p. 374). Reduzir a fala e intensificar a audição em meio ao povo foram mais algumas das muitas lições do amigo: na carta de 10 de março de 1926, Mário recomendava a Drummond que ficasse em companhia da gente simples, da sua pequena cidade em Minas Gerais, para aprender com suas vozes sábias:

Você aí procure se dar com toda a gente, procure se igualar com todos, nunca mostre nenhuma superioridade principalmente com os mais humildes e mais pobres de espírito. Viva de preferência com colonos e gente baixa que com delegados e médicos. Com a gente baixa você tem muito que aprender [...]. Faça de todos o seu aprendizado contínuo, [...]. (ANDRADE, 2002, p. 204).

Mário de Andrade silenciou para ouvir a "gente de pé-no-chão" e também se calou quando seus pés não mais pisaram o chão da sua casa,

\footnotetext{
${ }^{23}$ Os versos mais longos do poema (de até vinte e quatro sílabas poéticas) também estão nessa seção.

${ }^{24}$ A expressão entre aspas é título de um romance de Fiódor Dostoiévski, autor admirado por Drummond e Mário.
} 
passando seu mutismo a ser ouvido em todos os cômodos: "Telegramas/ irrompem. Telefones/ retinem. Silêncio/ em Lopes Chaves". Nenhuma palavra, apenas a imagem muda nos noticiários, a figura quieta remembrada: "É um retrato, somente um retrato,/ algo nos jornais, na lembrança". O vocábulo "retrato" pode significar tanto um quadro pintado como fotografia. Esta aparece em muitos poemas de Drummond, geralmente associada a contextos de perda e esboroamento, como em "Confidência do Itabirano": "Tive ouro, tive gado, tive fazendas./ Hoje sou funcionário público/ Itabira é apenas uma fotografia na parede./ Mas como dói".

Para Roland Barthes, o instantâneo e a morte têm fundas ligações, pois o próprio material de que é feito a fotografia está condenado ao perecimento: seu papel é mortal e "como um organismo vivo, nasce dos próprios grãos de prata que germinam, desabrocha por um instante, depois envelhece. Atacada pela luz, pela umidade, ela empalidece, extenua-se, desaparece" (BARTHES, 1984, p. 139). O texto barthesiano é de 1980, mas, quarenta anos antes, Drummond já abordava poeticamente o assunto, em "Os mortos de sobrecasaca". Nesse texto, os falecidos têm seus sobretudos carcomidos por um verme que não dispensa as páginas, as dedicatórias e a poeira dos retratos, mas... não consegue roer "o imortal soluço de vida que rebentava/ que rebentava daquelas páginas". Morto é, portanto, morto, porém morto é vivo, em contextos drummondianos, do mesmo modo como Octavio Paz afirma que em poesia "isto é isto e aquilo é aquilo; e ao mesmo tempo, isto é aquilo" (PAZ, 1982, p. 121).

Em "Mário de Andrade desce aos infernos", o retrato aparece num contexto negativo, no qual o pesar, a mudez entranhada de tom lúgubre ${ }^{25}$ e o vazio retornam ao poema (depois do momento mais luminoso da sua terceira seção) e repercutem no sujeito enunciador: "Agora percebemos que estamos amputados e frios// [...] o dia estragado como uma fruta,/ um véu baixando, um ríctus,/ o desejo de não conversar. É sobretudo uma pausa oca/ e além de todo vinagre" (os grifos são meus).

Porém, versos à frente, volta a luz ("mais perto, e uma lâmpada"), quando a casa do morto é visitada pela imaginação do sujeito poético e quando são vistos quadros de Portinari, Cézanne e Picasso nas suas paredes. O silêncio se colore nesses versos. Segundo Simonides de Cós, a pintura é a "a poesia muda" (apud PRAZ, 1982, p. 3), mas é possível fundir a não-palavra pictórica com o verbo poético. É o que fizeram muitas vezes Drummond (inclusive no poema em análise) e Dante, cuja obra maior foi

\footnotetext{
${ }^{25}$ É importante observar que o silêncio não tem significados exclusivamente negativos, pois ele, semanticamente, avulta-se como "o reduto do múltiplo", nas palavras de Eni Puccinelli Orlandi, podendo ser, por exemplo, de contemplação, introspecção, resistência, perda da vontade etc. (ORLANDI, 1995, p. 44).
} 
representada por Jorge Luis Borges como "uma estampa pintada há muitos séculos", contendo "todas as fábulas de As mil e uma noites", "uma árvore que parece um cone invertido", um romance com incontáveis personagens, o presente, o passado, o futuro etc. (BORGES, 2011, p. 9). Para Italo Calvino, haveria um parentesco da literatura de Dante com uma arte que ainda não tinha nascido no tempo do autor florentino, o cinema (CALVINO, 2002, p. 99). Parece cena de um filme uma passagem de Vida nova, provinda do sonho do enunciador em que pássaros despencam do céu e o impacto da sua queda no chão produz gigantescos terremotos. (ALIGHIERI,1993, p. 51).

Imagens de um cinema onírico também estão presentes nos versos da última parte do poema "Mário de Andrade desce aos infernos", em que a casa do autor paulistano desprende-se do solo e ganha os ares, transformando-se em "navio de São Paulo no céu nacional" e "viaja como um lento pássaro".

Depois desse deslocamento para o alto, o poema retoma, nos seus derradeiros versos, o movimento de descida, indicado no título ("Mário de Andrade desce aos infernos"): "Mas tua sombra robusta desprende-se e avança./ Desce o rio, penetra os túneis seculares/ onde o amigo marcou seus traços funerários,/ desliza na água salobra". O silêncio indicado dos versos antecedentes (a falta de resposta para telefonemas e telegramas) não toma o lugar do discurso da obra deixada; o verbo do morto se impõe na viva perenidade: "ficam tuas palavras (superamos a morte, e a palma triunfa)/ tuas palavras carbúnculo e carinhosos diamantes". Não me parece aleatória a escolha da pedra (carbúnculo e diamante) nessa homenagem de um autor saído de terras mineiras (e que cria uma obra plena de imagens pétreas) para outro escritor cujo texto mais conhecido tem também uma pedra com grande valor sentimental para seu protagonista (a Muiraquitã de Macunaíma). Identidade e afeto refulgem nesses versos.

Diferentemente do que encontrou Dante no inferno, Mário se depara, na descida, não com a luminosidade do fogo abrasador aguçando as dores dos condenados, mas sim com o resplendor das preciosidades que ele, Mário, deixou aos vivos para retirar seus sentimentos da escuridão: os escritos de "palavras carbúnculo", repletos de "carinhosos diamantes", enterrados como tesouros para aqueles que escavando as camadas textuais de sua obra encontram joias semânticas alojadas em seu quieto e denso subtexto.

"O resto é silêncio" e verbo cintilante...

\section{Referências bibliográficas}

ADORNO, Theodor. "O ensaio como forma". In: Notas de literatura I. Tradução de Jorge de Almeida. São Paulo: Duas Cidades: 34, 2003, p. 15- 
45.

ALIGHIERI, Dante. A divina comédia. 2 volumes, $2^{\mathrm{a}}$ edição. Tradução, notas e estudo biográfico de Cristiano Martins; ilustrações de Gustave Doré. Belo Horizonte: Itatiaia; São Paulo: Edusp, 1979.

AlIGHIERI, Dante. A divina comédia. Edição bilingue; $5^{\mathrm{a}}$ edição. Tradução e notas de Eugenio Mauro; prefácio de Carmelo Distante. São Paulo: 34, 2019.

AlighIERI, Dante. Vida nova. $3^{\text {a }}$ edição. Tradução de Carlos Eduardo Soveral. Lisboa: Guimarães Editores, 1993.

ANDRADE, Carlos Drummond de (org.). A lição do amigo: cartas de Mário de Andrade a Carlos Drummond de Andrade. Anotadas pelo destinatário; posfácio de André Botelho. São Paulo: Companhia das Letras, 2015.

ANDRADE, Carlos Drummond de Carlos \& Mário: correspondência de Carlos Drummond de Andrade e Mário de Andrade. Prefácio e notas de Carlos Drummond de Andrade e Silviano Santiago. Rio de Janeiro: Bemte-vi, 2002.

ANDRADE, Carlos Drummond de Poesia completa. Fixação de textos e notas de Gilberto Mendonça Teles; introdução de Silviano Santiago. Rio de Janeiro: Nova Aguilar, 2007.

Andrade, Mário de. Cartas de Mário de Andrade a Luís da Câmara Cascudo. Introdução e notas de Veríssimo de Melo. Belo Horizonte; Rio de Janeiro: Villa Rica, 1991.

ANDRADE, Mário de. Poesias completas. Edição de texto apurado, anotada e acrescida de documentos por Tatiana Longo Figueiredo e Telê Ancona Lopez. 2 volumes. Rio de Janeiro: Nova Fronteira, 2013.

ARRIGUCCI JR., Davi. Coração partido: uma análise da poesia reflexiva de Drummond. São Paulo: Cosac Naify, 2002.

AuERBACH, Erich. Dante, poeta do mundo secular. Tradução de Raul de Sá Barbosa. Rio de Janeiro: Topbooks, 1997.

BARTHES, Roland. A câmara clara: notas sobre a fotografia. Tradução de Júlio Castañon Guimarães. Rio de Janeiro: Nova Fronteira, 1984.

BENJAMIN, Walter. O narrador. In: Obras escolhidas: magia e técnica, arte e política: vol. 1. Tradução de Sérgio Paulo Rouanet; prefácio de Jeanne 
Marie Gagnebin. São Paulo: Brasiliense, 1994, p. 197-221.

BISCHOF, Betina. Razão da recusa: um estudo da poesia de Carlos Drummond de Andrade. São Paulo: Nankin, 2005.

BORGES, Jorge Luis. Nove ensaios dantescos \& a memória de Shakespeare. Tradução de Heloisa Jahn. São Paulo: Companhia das Letras, 2011.

BosI, Alfredo. “A máquina do mundo: entre o símbolo e a alegoria”. In: Céu, inferno. São Paulo: Duas Cidades: 34, 2003, p. 99-121.

BosI, Alfredo. O ser e o tempo da poesia. São Paulo: Cultrix: Edusp, 1977.

CALVINO, Italo. Seis propostas para o próximo milênio: lições americanas. $3^{\mathrm{a}}$. edição. Tradução de Ivo Barroso. São Paulo: Companhia das Letras, 2002.

CANDIDO, Antonio. Inquietudes na poesia de Drummond. In: Vários escritos. $2^{a}$ edição. São Paulo: Livraria Duas Cidades, 1977, p. 93-122.

DAll'AlBA, Eduardo. Drummond, leitor de Dante. Caxias do Sul: Educs, 1996.

DistANTE, Carmelo. "Prefácio". In: AlighIERI, Dante. A divina comédia. Edição bilingue; $5^{\mathrm{a}}$. edição. Tradução e notas de Eugenio Mauro. São Paulo: 34, 2019, p. 7-17.

ELIOT, T. S. "Tradição e talento individual". In: Ensaios. Tradução, introdução e notas de Ivan Junqueira. São Paulo: Art Editora, 1989, p. 3748.

FONSECA, Maria Augusta. "Ponteio da violinha: o rapsodo moderno e o herói sem nenhum caráter". In: ABDALA JR., Benjamin; CARA, Salete de Almeida (orgs.). Moderno de nascença: figurações críticas do Brasil. São Paulo: Boitempo, 2006, p. 103-119.

FONTElA, Orides. Poesia reunida (1969-1996). Rio de Janeiro: 7Letras; São Paulo: Cosac Naify, 2006.

GINZBURG, Jaime. "Carlos Drummond de Andrade: uma leitura de poemas da década de 1940 em perspectiva adorniana". In: Crítica em tempos de violência. São Paulo: Edusp: Fapesp, 2012, p. 331-338.

MERQUiOR, José Guilherme. Verso universo em Drummond. Tradução de Marly de Oliveira. Rio de Janeiro: José Olympio: Secretaria de Estado da Cultura, Ciência e Tecnologia, 1975. 
ORLANDI, Eni Puccinelli. As formas do silêncio: no movimento dos sentidos. Campinas: Editora da Unicamp, 1993.

PAZ, Octavio. “A imagem”. In: O arco e a lira. Tradução de Olga Savary. Rio de Janeiro: Nova Fronteira, 1982, p. 119-138.

PlutaRCO. Como ouvir. Prefácio e notas de Pierre Maréchaux; tradução (grego e francês) de João Carlos Cabral Mendonça; revisão da tradução de Henrique F. Cairus e Tatiana Ribeiro. São Paulo: Martins Fontes, 2003.

PONTIERI, Regina Lúcia. Clarice Lispector: uma poética do olhar. Cotia: Ateliê, 1999.

PRAZ, Mário. Literatura e artes visuais. São Paulo: Cultrix: Edusp, 1982.

SOUSA, Cruz e. "No inferno". In: Evocações. Rio de Janeiro: Tipografia Aldina, 1889, p. 231-239.

TITAN JR., Samuel. “Um poeta do mundo terreno”. In: ANDRADE, Carlos Drummond de Andrade. Claro enigma. São Paulo: Companhia das Letras, 2012, p. 111-124.

VILlAçA, Alcides. "O poeta, a máquina e o mundo". In: Passos de Drummond. São Paulo: Cosac Naify, 2006, p. 78-106.

Julio Augusto Xavier Galharte é mestre e doutor em Letras (Teoria Literária e Literatura Comparada) pela Universidade de São Paulo, com pós-doutorado em Teoria e História Literária pela Universidade Estadual de Campinas. Atualmente é professor contratado no Departamento de Teoria Literária e Literatura Comparada da USP. Atuou como professor na Universidade Estadual Paulista, campus de Araraquara, bem como na Universidade Federal do Mato Grosso do Sul e na Universidade Estadual do Mato Grosso do Sul. Organizou, com Danglei de Castro 
Pereira, o livro Baú de Barro(s) - ensaios sobre a poética de Manoel de Barros (Pontes, 2019); publicou, entre outros ensaios, "Na trilha da despalavra: silëncios em obras de Clarice Lispector e Samuel Beckett", capítulo do livro Leitores e leituras de Clarice Lispector, organizado pela professora Regina Lúcia Pontieri (Hedra, 2004). Contato: xgalharj@usp.br

ORCiD: https:// orcid.org/0000-0003-1862-0702 